\title{
Zbigniew Janczewski
}

\section{Materia i forma sakramentu małżeństwa}

Ius Matrimoniale 18 (24), 7-23

2013

Artykuł został opracowany do udostępnienia w internecie przez Muzeum Historii Polski w ramach prac podejmowanych na rzecz zapewnienia otwartego, powszechnego i trwałego dostępu do polskiego dorobku naukowego i kulturalnego. Artykuł jest umieszczony w kolekcji cyfrowej bazhum.muzhp.pl, gromadzącej zawartość polskich czasopism humanistycznych i społecznych.

Tekst jest udostępniony do wykorzystania w ramach dozwolonego użytku. 


\section{$\begin{array}{lllllllllllllllll}\mathbf{R} & \mathbf{O} & \mathbf{Z} & \mathbf{P} & \mathbf{R} & \mathbf{A} & \mathbf{W} & \mathbf{Y} & \mathbf{I} & \mathbf{A} & \mathbf{R} & \mathbf{T} & \mathbf{Y} & \mathbf{K} & \mathbf{U} & \mathbf{L} & \mathbf{Y}\end{array}$}

Ius Matrimoniale

$18(24) 2013$

\section{Ks. Zbigniew Janczewski \\ UKSW}

\section{MATERIA I FORMA SAKRAMENTU MALŻEŃSTWA}

Kiedy dwie osoby ochrzczone zawierają małżeństwo, otrzymują specjalny udział w dobrach Mistycznego Ciała Chrystusa. Chrystus udziela swoich łask, potrzebnych dla utrzymania i rozwoju ich związku. Dołączają się również do wspólnoty tworzonej przez Chrystusa z Kościołem, którą w swoim małżeństwie odtwarzają i dopełniają. Jak naucza Sobór Watykański II, otrzymany sakrament umacnia i jakby konsekruje do obowiązków i godności ich stanu². To dla nich zwykły akt małżeński został przez Boga podniesiony do godności sakramentu.

Od stuleci teologowie i kanoniści starają się znaleźć samo jądro sakramentalnego znaku małżeństwa, wyrażanego poprzez słowa i gesty. Skoro małżeństwo jest sakramentem i dokonuje się w nim duchowe zjednoczenie, oraz zjednoczenie materialne ze względu na służbę naturze ludzkiej i społeczeństwu, potrzeba, aby mocą Bożą to zjednoczenie duchowe dokonywało się za pośrednictwem zjednoczenia materialnego ${ }^{2}$. Takie dwa elementy, podobnie jak w przypadku wszystkich sakramentów, tworzą ich materię i formę. Problem materii i formy sakramentu małżeństwa jest na tyle skomplikowany, że autorzy omawiający małżeństwo zazwyczaj o nim nie wspominają, albo też niejako „prześlizgują” się nad nim, traktując zdawkowo za pomocą dwóch trzech zdań. Przypatrzmy się mu zatem bliżej.

Interesujące nas zagadnienie zostanie omówione w trzech częściach. W pierwszej znajdzie się jego krótki rys historyczny, kolejne punkty będą dotyczyły materii sakramentu małżeństwa oraz jego formy. Na zakończenie zajmiemy się problemem wad powodujących nieważność małżeństwa.

\footnotetext{
${ }^{1}$ Konstytucja dogmatyczna o Kościele, Gaudium et spes, nr 48.

2 S. Tomasz z Akwinu, Summa theologica, Suppl. 45, 1.
} 


\section{Rys historyczny}

Sakramenty są znakami, które odzwierciedlają zbawienie, za ich pośrednictwem tajemnica zbawienia dokonuje swego dzieła w osobach przyjmujących. Istotą wydarzenia sakramentalnego jest to, że łaska z nim związana, w jej przekazywaniu, łączy się ściśle z elementami widzialnymi, nazywanymi znakami - widzialnymi znakami daru łaski niewidzialnej. Bóg w porządku sakramentalnym zespala swoje dary nadprzyrodzone $\mathrm{z}$ naturalnym znaczeniem znaków ${ }^{3}$. Znak sakramentalny składa się z gestu wykonywanego za pomocą słów i czynności, uobecniającej tajemnice paschalne. Słowo, nazywane też formułą sakramentalną, jest „formą” działania, tego działania, które może się posługiwać elementami materialnymi, nazywanymi w terminologii scholastycznej „materią” sakramentów. Słowa wypowiadane przez szafarzy podczas sprawowania wszystkich sakramentów, stają się ściśle „formą”, określoną w ten sposób, aby znaczenie sakramentu było jasne i doprecyzowane. „Materia” ukazuje więź ze światem otaczającym człowieka oraz zbawczymi gestami samego Jezusa Chrystusa ${ }^{4}$.

Proces kształtowania się materii i formy sakramentu małżeństwa dokonywał się na przełomie kilku wieków historii Kościoła, przy czym zauważa się nieco odmienne podejście do tejże kwestii w Kościele katolickim i prawosławnym. W świetle teologii małżeństwa wydaje się, że małżeństwo jest sakramentem, w którym najtrudniej było wyróżnić jego materię i formę. Za jego formę błędnie uznawano na przykład wolę rodziców, przełożonych, publiczne ogłoszenie związku lub wyznanie miłości, umowę prawną czy stosunek seksualny. Jeszcze bardziej skomplikowany jest problem ustalenia materii i formy w katolickich Kościołach wschodnich, które przyjęły w znacznej mierze rzymskokatolicką naukę o sakramencie małżeństwa ${ }^{5}$.

Trudność ta wynika między innymi z faktu, że Jezus ustanawiając sakrament małżeństwa, dokładniej podnosząc małżeństwo chrześcijan do godności sakramentu, nie określił wprost jego materii i formy. Stwierdził jedynie, że mężczyzna i kobieta, łączą się w związek

${ }^{3}$ B. Testa, Sakramenty Kościoła, tłum. L. Balter, Poznań 1998, s. 69.

4 Z. Janczewski, Ważność sprawowania sakramentów wtajemniczenia chrześcijańskiego, uzdrowienia i święceń w porzadku prawnym Kościoła katolickiego, Warszawa 2011, s. 160.

${ }^{5}$ M. Blaza, D. Kowalczyk, Traktat o sakramentach, w: Dogmatyka, t. 5, Warszawa 2007 , s. 476. 
tworzony przez Boga i nierozwiązalny ludzką mocą ${ }^{6}$. Stąd też już w pierwszych wiekach chrześcijaństwa nie istniał jednolity obrzęd zawierania małżeństwa. Najpierw miały miejsce zaślubiny w formie „cywilnej” po czym para chrześcijan udawała się do biskupa, aby w ramach sprawowania Eucharystii przyjąć Komunię św. i specjalne błogosławieństwo, które niejako ,przypieczętowywało” małżeństwo chrześcijańskie ${ }^{7}$. To błogosławieństwo było przez Tertuliana $(+230)$ uznawane za istotny element sakramentu. ${ }^{8}$ Na Wschodzie omawiany sakrament był zawsze celebrowany podczas liturgii Mszy, rozumianej jako źródło wspólnoty małżeńskiej.

Tymczasem w Kościele łacińskim podczas obrzędu zawierania małżeństwa za najistotniejszy element sakramentu zaczęto uważać wyrażenie przez nupturientów zgody małżeńskiej. Potwierdzeniem tej tezy jest list papieża Mikołaja I do Borysa - cara Bułgarii z 866 r. Papież pisze, że do ważności małżeństwa nie jest konieczne błogosławieństwo kapłana, wystarczy bowiem wyrażona zgodnie z prawem zgoda tych, którzy chcą się pobrać. Jeżeli tej zgody w małżeństwie zabrakło, wszystko inne nie ma znaczenia ${ }^{9}$. Należy zauważyć, iż kształtująca się chrześcijańska liturgia małżeństwa, przejmując z różnych kultur, w których była sprawowana zastałe formy łączenia mężczyzny i kobiety w jedna rodzinę, tchnęła w nie nowego ducha, nową wizję pozostawioną przez Chrystusa. Novum było w niej również sprawowanie podczas obrzędu Eucharystii ${ }^{10}$.

Zgoda małżeńska (nazywana też konsensem), została w średniowieczu dokładniej opisana przez Hugona od św. Wiktora $(+1141)$. Jest ona wzajemnie wymieniana przez nupturientów i stanowi nie tylko zwykłe przyrzeczenie na przyszłość, ale wyraźną intencję zawarcia małżeństwa. Ponadto i przede wszystkim to przyczyna sprawcza małżeństwa ${ }^{11}$. Piotr Lombard $(+1160)$ dodaje, iż małżeństwo istnieje od samego momentu wyrażenia zgody przez strony, słowami albo znakami,

Mt 19, 6.

7 B. Nadolski, Liturgika. Sakramenty, sakramentalia, błogosławieństwa, t. 3, Poznań 1992, s. 194-195.

8 J.M. Millas, Il sacramento del matrimonio. Elementi fonamentali, w: Matrimonio e sacramento, Studi Giuridici LXV, Città del Vaticano 2004, s. 9.

${ }^{9}$ Denzinger, 643.

${ }^{10}$ B. Nadolski, dz. cyt., s. 197.

${ }^{11}$ J. Hendrix, Diritto matrimoniale. Commento ai canoni 1055-1165, del Codice di Diritto Canonico, Milano 1999, s. 44-45. 
przy czym nie wystarcza wewnętrzne wypowiedzenie „tak”12. Konieczność wyrażenia zgody w danej chwili podkreślił papież Innocenty III w liście Ex parte tua z 1200 r. Natomiast Sobór Florencki w bulli unii z Ormianami Exultate Deo (1439) i unii z Koptami Cantate Domino (1442) naucza, iż w zwyczajnych warunkach przyczyną sprawczą małżeństwa jest wzajemna zgoda stron, wyrażona słowami w czasie teraźniejszym ${ }^{13}$.

Wymiana konsensu odbywała się w średniowieczu przez wypowiedzenie nupturientów słowa ,tak”, będącego odpowiedzią na postawione przez kapłana pytania o wolę zawarcia sakramentu. Istniały również bardziej rozwinięte formuły liturgiczne, zawierające zwrot: ,,ja biorę sobie ciebie za żonę (męża)..." Pojawił się też gest łączenia rąk, stanowiący jednak tylko symbol wzajemnego oddania się małżonków, co wyrażały towarzyszące temu znakowi słowa. Można powiedzieć, że od XII w. małżeństwo chrześcijańskie stało się „kościelnym”, czyli sprawą Kościoła, zarówno w perspektywie jurydycznej, jak i liturgicznej ${ }^{14}$.

$\mathrm{Na}$ Wschodzie, podobnie jak na Zachodzie, w pierwszych wiekach chrześcijaństwa małżeństwa zawierane bez udziału Kocioła uznawane były za ważne. Jednakże tutaj większą wage przywiązywano do formy zawierania związku, uroczystej ceremonii, kapłańskiego błogosławieństwa ${ }^{15}$. Kościół Wschodni domagał się od samego początku, aby wierni przystępowali do małżeństwa za jego wiedzą i z błogosławieństwem kapłańskim ${ }^{16}$. W IV w. uformował się już ryt zaślubin właściwy chrześcijaństwu wschodniemu, coraz częściej mówiło się również o obecności kapłana podczas takiego obrzędu ${ }^{17}$. Ceremonie zawierały trzy istotne elementy, stanowiące jakby trzy etapy celebracji: zaręczyny, błogosławieństwo małżonków i ich koronację ${ }^{18}$. Modlitwa błogo-

${ }^{12}$ P. Lombard, Sententiarum libri quattuor, dist. 27 n. 3, t.4, Antwerpia 1757.

${ }^{13}$ Dokumenty soborów powszechnych. Tekst grecki, laciński, polski, opr. Baron H., Pietras H., t.3, Kraków 2004, s. 523; 615.

${ }^{14}$ B. Nadolski, dz. cyt., s. 198-199.

${ }^{15}$ U. Nowicka, Szafarz sakramentu matżeństwa. Studium historyczno-prawne, Wrocław 2007, s. 89.

${ }^{16}$ T. Gromnicki, Forma zaręczyn i matżeństwa wedtug dekretu „,Ne temere”, Kraków 1910, s. 17.

${ }^{17}$ K. Stevenson, Nuptial Blessing. A study of Christian Marriage, Colchester London 1982, s. 22-24.

${ }^{18}$ A. Raes, Le consentement matrimonial dans les rites orientaux, Ephemerides Liturgicae 47(1933) s. 35. 
sławieństwa była traktowana jako środek, przez który Kościół wzywa pomocy bożej, aby towarzyszyła małżonkom i ich nowemu życiu ${ }^{19}$. Błogosławieństwa udzielał kapłan, przewodniczący liturgii zaślubin podczas Mszy św. ${ }^{20}$.

W liturgii bizantyjskiej, w której pytał on narzeczonych o ich intencję zjednoczenia się $\mathrm{w}$ małżeństwie, następowało błogosławieństwo obraczek narzeczonych oraz koronacja i błogosławieństwo narzeczonych. Podobnie liturgia maronicka składała się z pytań kapłana $\mathrm{o}$ wyrażenie zgody na małżeństwo oraz z błogosławieństwa i koronacji. Natomiast w liturgii Koptów wolę narzeczonych wyrażała wymiana pobłogosławionych obrączek, po której następowała koronacja małżonków ${ }^{21}$. W kontekście materii interesującego nas sakramentu według Daquino, najistotniejszym obrzędem podczas zawierania małżeństwa na Wschodzie była koronacja, czyli akt nałożenia wieńców na głowy małżonków, z którą w ścisłym związu pozostawało równie ważne i doniosłe błogosławieństwo kapłańskie. Jednakże przyjęcie tego błogosławieństwa było bardziej obowiązkiem moralnym niż prawnym, traktowanym jako zaszczyt i przywilej chrześcijan ${ }^{22}$. Cytowany autor nie ma chyba do końca racji, ponieważ przytoczony wcześniej list papieża Mikołaja I z 866 r. stwierdza powszechną praktykę błogosławienia małżeństw w Kościele bizantyjskim i zdaje się zakładać konieczność takiego błogosławieństwa dla ważności małżeństw ${ }^{23}$. O słuszności tej tezy świadczą postanowienia synodów prowincjalnych Kościołów wschodnich z tamtych czasów ${ }^{24}$ oraz słowa patriarchy Konstantynopola Nikifora (806-815), stwierdzającego, że związek, który został zawarty bez kapłańskiego błogosławieństwa jest konkubinatem ${ }^{25}$.

${ }^{19} \mathrm{G}$. Kadzioch, Il ministro del sacramento del matrimonio nella tradizione e nel diritto canonico latino e orientale, Roma 1997, s. 78.

${ }^{20} \mathrm{~K}$. Ritter, Formen, Riten Und religioses Brauchtum der Eheschlieaung in der christlichen Kirchen des ersten Jahrtausendes, Munster 1962, s. 82-83.

${ }^{21}$ A. Raes, Le mariage dans les Eglises d'Orient, Chevetogne 1958, s. 25.

${ }^{22}$ P. Daquino, Storia del matrimonio christiano alla luce della Biblia, Torino 1984, s. 345 .

${ }^{23}$ U. Nowicka, Szafarz sakramentu matżeństwa..., s. 94.

${ }^{24}$ Por. np. uchwały Kościoła ormiańskiego, Collectio Canonum Apostolorum IV sec., w: Fonti Codificazione Canonica Orientale, ser. II, z. XXI, Cita del Vaticano 1935, s. 26.

${ }^{25}$ J.B. Pitra, Ius ecclesiastici Graecorum historia et monumenta, t.2, Roma 1868, s. 346 . 
Od VIII w. ustawodawstwo bizantyjskie uznawało błogosławieństwo małżeństw w Kościele jako jedną z form związku zawieranego ważnie na forum cywilnym. Od tej pory w Kościele bizantyjskim, a później w innych, za ważne uważano zarówno małżeństwa zawierane za zgodą stron w obecności świadków, jak i z błogosławieństwem Kościoła ${ }^{26}$. Około roku 893 cesarz Leon Filozof nakazał zawieranie związków małżeńskich w formie kościelnej, z błogosławieństwem kapłana i tylko takim zapewnił ważność w obliczu prawa cywilnego ${ }^{27}$. W XI w. obrzędy liturgiczne stały się w koncepcji prawnej grecko-bizantyjskiej formą obligatoryjną kontraktu małżeńskiego, zaakceptowaną z czasem w innych Kościołach wschodnich ${ }^{28}$.

\section{Materia sakramentu}

Począwszy od XIII w. uznani teolodzy, jak Hugo od św. Wiktora, Aleksander de Halles, św. Tomasz z Akwinu, zaczęli wyróżniać w znaku sakramentalnym współzależne od siebie dwa elementy materię i formę ${ }^{29}$. Każdy sakrament, stanowiąc materialny i widzialny znak, zawiera w sobie element materialny, nazywany jego materią. Określenie materii jest najłatwiejsze w przypadku chrztu, bierzmowania, Eucharystii oraz namaszczenia chorych, natomiast w odniesieniu do pozostałych nie jest już takie proste ${ }^{30}$. Od późnego średniowiecza rozróżniano także dalszą materię sakramentów (materia remota), odnoszącą się do rzeczy jako takiej, związanej z danym sakramentem i materię bliższą (materia proxima), czyli użycie tej rzeczy podczas liturgii sprawowania sakramentu ${ }^{31}$. Dzisiaj materia określana jest jako esencjalny, niewerbalny element sakramentu, konieczny do jego ważności ${ }^{32}$.

Tak jak to już zostało powiedziane, określenie materii sakramentu małżeństwa stanowi pewną trudność. W teologicznym opracowa-

\footnotetext{
${ }^{26}$ U. Nowicka, Szafarz sakramentu małżeństwa..., s. 96.

${ }^{27}$ Leo VI Philosophus, Nov. 89, w: PG 107, 602.

${ }^{28}$ E. Schilleebeckx, Il matrimonio. Realtà terrena e mistero di salvezza, Roma 1971 , s. 322

${ }^{29}$ E. Besson, La dimension juridique des sacraments, Roma 2004, s. 199.

${ }^{30}$ Z. Janczewski, dz. cyt., s. 162.

${ }^{31}$ M. Blaza, D. Kowalczyk, dz. cyt., s. 248.

${ }^{32}$ J.M. Huels, Liturgy and Law. Liturgical Law in the System of Roman Catholic Canon Law, Montreal 2006, s. 189.
} 
niu tej tematyki zauważa się najpierw, iż chrześcijańskie małżeństwo nie ma żadnego własnego gestu, który musiałby być spełniony, ani też słów nadających temu gestowi konkretne znaczenie. Wszystko wynika tutaj z samego wyniesienia człowieka do łaski zakorzenionej i związanej z chrztem ${ }^{33}$. Po wtóre, interesująca nas kwestia jest inaczej ujmowana przez Kościół łaciński i Kościoły wschodnie. W odniesieniu do pierwszego z nich, jak trafnie zauważa Pawluk, materią jest wzajemne przekazanie siebie przez nowożeńców, wyrażone słowami lub innymi znakami, w celu ustanowienia nieodwracalnej wspólnoty małżeńskiej. Następstwem nierozerwalności umowy małżeńskiej i sakramentu małżeństwa, jest również to, że szafarzami sakramentu są nupturienci do niego przystępujący. Umowa małżeńska ochrzczonych nie różni się realnie od sakramentu małżeństwa, stąd też, kto ją zawiera, jest jednocześnie szafarzem sakramentu ${ }^{34}$. Konstytucja dogmatyczna o Kościele Lumen gentium Soboru Watykańskiego II deklaruje, że w interesującym nas sakramencie małżonkowie wzajemnie się sobie oddają i przyjmuja, a działanie Boga staje się widoczne nie tylko w prawnym akcie, ale w liturgicznej celebracji zawierania małżeństwa. Przymierze małżonków jest rzeczywistością o charakterze personalnym i religijnym. Ich konsens nie dotyczy jedynie wzajemnego prawa do ciała, ale ma znaczenie personalnego, wzajemnego zrozumienia, głębokiej wspólnoty życia i miłości ${ }^{35}$.

Nauczanie Soboru Watykańskiego II zostało syntetycznie sprecyzowane w Kodeksie prawa kanonicznego papieża Jana Pawła II. Czytamy w nim, że małżeństwo stwarza zgoda stron między osobami prawnie do tego zdolnymi, wyrażona zgodnie z prawem. Zgoda ta jest aktem woli, w którym mężczyzna i kobieta w nieodwołalnym przymierzu wzajemnie się sobie oddają i przyjmują w celu stworzenia małżeństwa ${ }^{36}$.

Materię sakramentów, jak to już zostało wspomniane stanowi nieodzowny element materialny, będący widzialnym znakiem dla całej wspólnoty Kościoła. Reasumując można powiedzieć, że w przypadku małżeństwa, w Kościele łacińskim (co podkreśla również Katechizm Kościoła Katolickiego), tym nieodzownym elementem , je stwarzają-

${ }^{33}$ B. Testa, Sakramenty Kościoła, tłum. L. Balter, Poznań 1998, s. 356.

${ }^{34}$ T. Pawluk, Prawo kanoniczne wedtug kodeksu Jana Pawła II, t.2, Lud Boży jego nauczanie i uświęcanie, Olsztyn 1986, s. 29.

${ }^{35} \mathrm{KDK} 48$.

${ }^{36}$ Kan. 1057 KPK. 
cym" jest wzajemne wyrażenie zgody przez małżonków. Jeżeli nie ma takiej zgody, nie ma też małżeństwa ${ }^{37}$. Posługa małżonków realizuje się przeto w samym zawieraniu umowy małżeńskiej, wykonanie gestu konsensualnego, przynosi im samo przez się łaskę sakramentalną ${ }^{38}$.

Odmiennie kwestia materii sakramentu małżeństwa przedstawia się w ujęciu prawosławnym. Tam bowiem małżeństwo staje się niejako przejściem do prawdziwego życia, wprowadzając zaślubionych w głębię bóstwa i człowieczeństwa Zbawiciela. Dwie osoby nawiązują wspólnie niezwykłą relację ze zmartwychwstałym i królującym Chrystusem, Jego śmierć i zmartwychwstanie stanowią więc podstawę tej nowej, radykalnej relacji pomiędzy małżonkami ${ }^{39}$. Małżeństwo jest mistycznym odzwierciedleniem Kościoła, spójnią męża i żony na wzór jedności Boga-Człowieka i Jego Ciała-Kościoła, szczególnym przymierzem małżonków z Bogiem ${ }^{40}$. Również w prawosławiu nupturienci muszą wyrazić swoją zgodę, aby zjednoczyć się jako mąż i żona, jednakże zgoda ta, będąca przyczyną każdego innego, zwyczajnego, kontraktu, według Pradera nie może mieć mocy ustanowienia sakramentu. W tym właśnie małżeństwo „w Panu” różni się od związku cywilnego, że jest uświęcane przez łaskę Bożą, która może na nie zstapić poprzez błogosławieństwo kapłańskie. W koncepcji prawosławnej przymierze małżeńskie nie staje się sakramentem na mocy wzajemnej zgody małżonków, ale poprzez interwencję kapłana, szafarza sakramentu ${ }^{41}$. Jak pisze Evdokimov, jeśli narzeczeni wyrażają swoją miłość wobec kapłana, modlitwa inwokacyjna błogosławieństwa Bożego przekształca tę miłość w sakrament ${ }^{42}$. Tak więc podczas gdy w Kościele katolickim wzajemna zgoda stron jest przyczyną sprawczą kontraktu-sakramentu, jako jednej rzeczywistości, to w Ko-

${ }^{37}$ Katechizm Kościoła Katolickiego, nr 1626, Poznań 1998.

${ }^{38}$ B. Testa, dz. cyt., s. 355.

${ }^{39}$ A. C. Calivas, Życie sakramentalne, w: Prawosławie. Światło wiary i zdrój doświadczenia, red. K. Leśniewski, J. Leśniewska, Lublin 1999, s. 198.

${ }^{40}$ S. Hrycuniak, Prawosławne pojmowanie matżeństwa $w$ teologii prawosławnej, Warszawa 1977, s. 53.

${ }^{41}$ J. Prader, Aspetti specifici nel Codice orientale rispetto al Codice Latino in materia matrimoniale, w: Gruppo Italiano Docenti di Diritto Canonico, Matrimonio e disciplina ecclesiastica. XXI Incotnro Studio Passo della Mendola-Trento 4-9.07.1994, Quaderni della Mendola, z. 3, Milano 2002, s. 48-49.

${ }^{42}$ P. Evdokimov, Sakrament miłości. Tajemnica matżeństwa w świetle tradycji prawosławnej, Białystok 2007, s. 212. 
ściele prawosławnym konsens określa kontrakt, nie identyfikując się $\mathrm{z}$ sakramentem ${ }^{43}$.

Jeżeli zaś chodzi o katolickie Kościoły wschodnie, uznające zwierzchnictwo Stolicy Apostolskiej, jak wyjaśnia Prader, interesujący nas znak sakramentalny wspólistnieje istotowo w niedyspensowanej zgodzie stron oraz za przyczyną takiego postanowienia Kościoła, w błogosławieństwie kapłańskim, które jest również istotnym elementem dla formy sakramentu małżeństwa ${ }^{44}$. Błogosławieństwo jest konieczne do ważności małżeństwa ${ }^{45}$. Według Blazy i Kowalczyka w skład materii wchodzi również wzajemną miłość nupturientów ${ }^{46}$. Twierdzenie to jest nieco kontrowersyjne. Po pierwsze dlatego, że pojęcie „miłość” jest niezwykle trudne do zdefiniowania, a tym bardziej do uchwycenia. Po drugie, powstaje poważna wątpliwość w odniesieniu do związków zawieranych przed laty przez strony, które po raz pierwszy widziały się i poznawały podczas ceremonii swoich zaślubin. Trudno więc było mówić o łączącej ich miłości. Brakowało w tym przypadku tego rzekomo istotnego dla powstania sakramentu elementu. Podejście katolickich Kościołów wschodnich jest więc nieco inne niż Kościoła prawosławnego, dla którego jak to zostało powiedziane wcześniej, elementem konstytutywnym sakramentu małżeństwa jest jedynie błogosławieństwo ${ }^{47}$.

Materię sakramentu stanowi istotny element, bez którego nie można go ważnie udzielić. W przypadku małżeństwa jak widzimy, mamy do czynienia aż z dwoma, a ewentualnie nawet $\mathrm{z}$ trzema takimi elementami. W przypadku Kościoła katolickiego jest nim zgoda małżonków, w Kościele prawosławnym - błogosławieństwo małżonków przez kapłana (prezbitera albo biskupa) i w końcu w katolickich Kościołach wschodnich materię stanowią konsens, błogosławieństwo i być może również wzajemna miłość nupturientów. Przy tak dużej różnorodności ujmowania interesującej nas kwestii wydaje się, że przy dobrej woli i chęci panującej w tych Wspólnotach, istniałaby możliwość porozu-

${ }^{43}$ U. Nowicka, Stwierdzenie stanu wolnego wiernych prawosławnych na forum Kościoła katolickiego, Warszawa 2012, s. 69.

${ }^{44} \mathrm{~J}$. Prader, La forma di celebrazione del matrimonio, w: Il matrimonio nel Codice dei Canoni delle Chiese orientali, Città del Vaticano 1994, s. 288.

${ }^{45}$ Kan. 828 KKKW; Katechizm Kościoła Katolickiego, nr 1634, Poznań 1998.

${ }^{46}$ M. Blaza, D. Kowalczyk, dz. cyt., s. 477.

${ }^{47}$ J. Prader, La forma di celebrazione del matrimonio..., s. 288. 
mienia się w sprawie ujednolicenia materii sakramentu. Wszak władzę ku temu, posiadają one z woli Chrystusa.

\section{Forma sakramentu}

Formą sakramentu w ujęciu klasycznym są słowa wypowiadane przez szafarza, podczas sprawowanego sakramentalnego obrzędu. Nie musi być ona jednak w sposób literalny, do końca utożsamiana ze słowem. Tezę taką potwierdza możliwość zawierania sakramentalnego związku małżeńskiego przez osoby głuchonieme ${ }^{48}$. Zgodnie z normą Kodeksu prawa kanonicznego z 1983 r. przysięga małżeńska może być wyrażona równoznacznymi znakami ${ }^{49}$, na przykład przy zastosowaniu języka migowego, albo też pisemnego oświadczenia ${ }^{50}$.

Dwa istotne elementy - forma i materia, nieodzowne dla ważnego sprawowania wszystkich sakramentów, przypominają o swoistym hylomorfiźmie, napięciu występującym pomiędzy słowem a obrzędem. Słowo wypowiadane podczas dokonywania obrzędu, nie może być traktowane przedmiotowo i abstrakcyjnie, należy zawsze doceniać wymiar eklezjalny i paschalny sakramentu. W Kościołach wschodnich każde rozróżnienie materii i formy sakramentów jest rozumiane zawsze w nawiązaniu do Wcielenia Syna Bożego oraz w kontekście Jego działalności na ziemi ${ }^{51}$.

Zatem, jak to już zostało powiedziane, formę sakramentów, w tym małżeństwa, stanowią zasadniczo istotne słowa wypowiadane przez szafarza podczas ich sprawowania. Słowa te zawierają się w formule, przewidzianej przez prawo liturgiczne. Forma sakramentu jest nieważna, jeżeli słowa formuły wypowiedzianej przez szafarza istotnie różnią się od tych które przewidują księgi liturgiczne ${ }^{52}$.

Omawiając formę sakramentu małżeństwa należy ponadto wyraźnie rozróżnić formę zawarcia małżeństwa określaną przez prawo kanoniczne i formę sakramentu małżeństwa, ujmowaną prawem liturgicznym. Pierwsza może być zwyczajna lub nadzwyczajna. W formie zwyczajnej małżeństwo zawiera się wobec asystującego miejscowego ordynariusza lub proboszcza, albo kapłana czy diakona delegowane-

\footnotetext{
${ }^{48}$ Z. Janczewski, dz. cyt., s. 218-219.

${ }^{49}$ Kan. 1104 § 2 KPK.

${ }^{50}$ M. Blaza, D. Kowalczyk, dz. cyt., s. 248-249.

${ }^{51}$ Tamże, s. 249.

${ }^{52}$ Z. Janczewski, dz. cyt., s. 219-220.
} 
go przez jednego z nich oraz w obecności dwóch świadków. Nadzwyczajną stosuje się, kiedy nie ma osoby kompetentnej do asystowania, lub nie można się z nią spotkać bez większej niedogodności i podczas ceremonii obok nupturientów obecni są jedynie świadkowie ${ }^{53}$.

Formę sakramentu małżeństwa w Kościele łacińskim, jak pisze Pawluk, stanowi przyjęcie i przekazanie prawa do siebie ${ }^{54}$. Jest nią więc zgoda małżeńska, wyrażana przez nupturientów zgodnie z prawem, przede wszystkim słowami przewidzianymi w prawie liturgicznym $^{55}$. Słowa te znajdujemy w księdze liturgicznej - Obrzędach sakramentu matżeństwa. Ciekawym jest fakt, iż obrzędy niejako dwukrotnie przewidują wypowiedzenie przez nupturientów konsensu. Najpierw kapłan zadaje im pytania dotyczące, jak czytamy w rubryce, dobrowolnej zgody na małżeństwo, woli wytrwania w wierności oraz gotowości na przyjęcie i wychowanie potomstwa: „...czy chcecie dobrowolnie i bez żadnego przymusu zawrzeć związek małżeński? ... czy chcecie wytrwać w tym związku w zdrowiu i w chorobie, w dobrej i złej doli, aż do końca życia? ...czy chcecie z miłością i po katolicku wychować potomstwo, którym was Bóg obdarzy?" Oboje równocześnie, trzykrotnie odpowiadają: „,chcemy”

W innej rubryce znajduje się norma liturgiczna, zgodnie z którą kapłan zwraca się do narzeczonych, aby wyrazili zgodę małżeńską słowami: ,Ja ... biorę ciebie, ..., za żonę (męża) i ślubuję ci miłość, wierność i uczciwość małżeńską oraz że cię nie opuszczę aż do śmierci. Tak mi dopomóż Panie Boże wszechmogący, w Trójcy jedyny i wszyscy święci" ${ }^{57}$. Należy w tym miejscu postawić pytanie: która $\mathrm{z}$ dwóch wymienionych formuł stanowi formę zawarcia sakramentu? Odpowiedź znajdujemy u Nadolskiego. Pierwszy z przytoczonych tekstów liturgicznych nazywa się skrutynium. Są to pytania wstępne proklamujące w działaniu liturgicznym, w obliczu całej zgromadzonej wspólnoty warunki wymagane do zawarcia małżeństwa. Natomiast

\footnotetext{
${ }^{53}$ Kan. $1108 ; 1116$ KPK.

${ }^{54}$ T. Pawluk, dz. cyt., s. 29.

${ }^{55}$ Tak jak to już zostało wspomniane wcześniej, zgoda może być wyrażona w inny sposób niż za pomocą słów.

${ }^{56}$ Obrzędy sakramentu matżeństwa dostosowane do zwyczajów diecezji polskich, nr 25, Katowice 1986.

${ }^{57}$ Tamże, nr 27.
} 
drugi tekst jest właśnie uroczystym wyrażeniem konsensu ${ }^{58}$, zawierającym równocześnie w sobie formę sakramentu.

W Kościołach wschodnich, prawosławnych i katolickich, w których formę stanowią formuły błogosławieństwa kapłańskiego, liturgie tam celebrowane zawierają wiele tekstów, w których prosi się Boga o łaskę i błogosławieństwo dla nowożeńców ${ }^{59}$. I tak przykładowo w Kościele bizantyjskim po wyrażeniu konsensu przed ikonostasem, para udaje się z zapalonymi świecami przed ołtarz, gdzie następuje wręczenie obrączek i rozbudowana modlitwa kapłańska, składająca się właściwie z trzech modlitw ${ }^{60}$. Formą sakramentu są słowa: „Zostaje ukoronowany(a) sługa Boży (służebnica Boża) ..., w imię Ojca i Syna i Ducha Swiętego. Amen" 61 . Ponadto u katolików wschodnich formułą sakramentalną jest również tekst przysięgi małżeńskiej.

Należy zatem zauważyć, że żadna z formuł stanowiących formę sakramentu nie została pozostawiona Kościołowi przez Chrystusa. Każda z nich ukształtowała się we Wspólnocie i została przez Kościół przyjęta, bądź to $\mathrm{w}$ formie zwyczaju, bądź też poprzez stworzenie konkretnego tekstu liturgicznego, najczęściej władzą najwyższego prawodawcy kościelnego, co miało między innymi miejsce po Soborze Watykańskim II.

\section{Wady materii i formy sakramentu powodujące nieważność malżeństwa}

Materia i forma sprawowania sakramentów są uważane zarówno w teologii jak i kanonistyce za jedne z czynników warunkujących ważność sprawowania sakramentów, w rozumieniu scholastycznym. Zasadniczo muszą być one aplikowane przez tego samego szafa$\mathrm{rza}^{62}$. Zasadniczo, bo w przypadku zawierania małżeństwa katolickiego przez pełnomocnika, sprawa przedstawia się nieco inaczej. Szafarzami omawianego sakramentu są nupturienci. Wypowiadając słowa przysięgi małżeńskiej, muszą posiadać wewnętrzny akt woli zawarcia małżeństwa. W tym momencie powinni też być równocześnie obecni,

\footnotetext{
${ }^{58}$ B. Nadolski, dz. cyt., s. 204-205.

${ }^{59}$ Katechizm Kościoła Katolickiego, nr 1624, Poznań 1998.

${ }^{60}$ B. Nadolski, dz. cyt., s. 202.

${ }^{61}$ Trebnyk, Lviv 2001, s. 77-78.

${ }^{62}$ Z. Janczewski, dz. cyt., s. 160-161.
} 
chyba że w imieniu którejś strony występuje właśnie pełnomocnik ${ }^{63}$. Pełnomocnik wypowiadając słowa przysięgi małżeńskiej aplikuje niejako formę sakramentu w imieniu swojego mocodawcy. Gdyby w tym samym czasie mocodawca cofnął swoją zgodę na małżeństwo, będzie to skutkowało jego nieważnością. Nieważne będzie również małżeństwo, podczas zawierania którego, jako pełnomocnik dla obu stron wystapi ta sama osoba, albo dla jednej strony drugi z nupturientów, wypowiadając formułę sakramentalną $\mathrm{w}$ imieniu swoim i zleceniodawcy. Jak trafnie bowiem zauważa Viladrich, jeżeli oboje nupturienci zawierają małżeństwo per procuratorem, nie mogą upoważnić tej samej osoby, ani też gdy pełnomocnictwa udziela jeden z nupturientów, nie może pełnomocnikiem ustanowić drugiego ${ }^{64}$.

Tak jak to już zostało wspomniane, nupturienci występujący osobiście podczas ceremonii małżeńskiej, muszą występować jednocześnie. Chodzi o obecność fizyczną. Nie wystarcza użycie listu, radia, czy też innych środków dla przekazania konsensu ${ }^{65}$. Nieważnym będzie więc małżeństwo, przy którego zawieraniu posłużono się współcześnie masowo używanymi środkami równoczesnej komunikacji, jak telefon komórkowy, albo internet. Zabraknie bowiem wypełnienia wymogu równoczesnej obecności fizycznej stron.

Pozostając w dalszym ciagu przy małżeństwie zawieranym w Kościele katolickim musimy zauważyć, że wady zgody małżeńskiej powodujące nieważność związku, stają się również przyczyną nieważności materii sakramentu. Wynika to pośrednio z faktu nierozdzielności kontraktu małżeńskiego i sakramentu. Jak trafnie zauważa Góralski, konsekwencją nadania przez Jezusa Chrystusa naturalnemu kontraktowi małżeńskiemu godności sakramentalnej, jest absolutna nierozdzielność u chrześcijan tych dwóch rzeczywistości. Prawda ta jest mocno ustalona w tradycji, nauczaniu Kościoła oraz jego ustawodawstwie, a także powszechnie przyjmowana $\mathrm{w}$ doktrynie $\mathrm{i}$ orzecznictwie sądowym $^{66}$. W tym miejscu, dla przypomnienia, należy wyliczyć wady zgody małżeńskiej zawarte w Kodeksie prawa kanonicznego z 1983 r. Należą do nich:

${ }^{63}$ Kan. $1104 \S 1$ KPK.

${ }^{64}$ P. J. Viladrich, Konsens matżeński. Sposoby prawnej oceny i interpretacji $w$ kanonicznych procesach o stwierdzenie nieważności matżeństwa, tłum. S. Świaczny, Warszawa 2002, s. 460.

${ }^{65}$ W. Góralski, Kanoniczna zgoda matżeńska, Gdańsk 1991, s. 243.

${ }^{66}$ W. Góralski, Studia nad matżeństwem i rodzina, Warszawa 2007, s. 144. 
a) brak wystarczającego używania rozumu,

b) poważny brak rozeznania oceniającego co do istotnych praw i obowiązków małżeńskich,

c) niezdolność do podjęcia istotnych obowiązków małżeńskich z przyczyn natury psychicznej ${ }^{67}$,

d) brak wystarczającej wiedzy o małżeństwie ${ }^{68}$,

e) błąd co do osoby, lub jej przymiotu ${ }^{69}$,

f) podstępne wprowadzenie w błąd ${ }^{70}$,

g) błąd co do jedności lub nierozerwalności, albo godności sakramentalnej małżeństwa ${ }^{71}$,

h) wykluczenie małżeństwa,

i) wykluczenie jego istotnego elementu lub przymiotu ${ }^{72}$,

j) małżeństwo zawarte pod warunkiem ${ }^{73}$,

k) małżeństwo zawarte pod wpływem przymusu i bojaźni ${ }^{74}$.

Tak jak to już zostało powiedziane, w Kościele prawosławnym za materię sakramentu małżeństwa uznaje się błogosławieństwo udzielane przez prezbitera albo biskupa. Nieważność materii powoduje zatem brak takiego błogosławieństwa podczas ceremonii liturgicznej, albo udzielenie go przez osobę nie posiadającą święceń kapłańskich.

Natomiast kryterium obiektywnym, decydującym o ważności formy sakramentu, jest przepisowe użycie słów formuły sakramentalnej, czyli wypowiedzianych przez szafarza, a w przypadku małżeństwa niemówiących również gestu przez nich wykonanego. Nupturienci wypowiadają słowa przysięgi małżeńskiej, używając wyrażeń odpowiednich i jasnych, lub też w przypadku kiedy nie potrafią mówić, równoznacznych znaków, aby uzewnętrznić wspólną intencję ustanawiającą małżeństwo. Wola wewnętrzna poszczególnego nupturienta, rozpatrywana pojedynczo i z osobna, bez jej wyrażenia zgodnie z prawem, nie ma siły sprawczej (brakuje tu bowiem formy sakramentu ${ }^{75}$. Forma sakramentu jest również nieważna, kiedy słowa wypowiadanej formuły istotnie różnią się od określonych przez Kościół i umieszczo-

\footnotetext{
${ }^{67}$ Kan. 1095 n. 1-3 KPK.

${ }^{68}$ Kan. 1096 KPK.

${ }^{69}$ Kan. 1097 KPK.

${ }^{70}$ Kan. 1098 KPK.

${ }^{71}$ Kan. 1099 KPK.

${ }^{72}$ Kan. 1101 KPK.

${ }^{73}$ Kan. 1102 KPK.

${ }^{74}$ Kan. 1103 KPK.

${ }^{75}$ P. J. Viladrich, dz. cyt., s. 451-452.
} 
nych w księdze liturgicznej. Dopuszczona jest jedynie ich drobna modyfikacja, zmiana akcydentalna ${ }^{76}$.

W latach siedemdziesiątych i osiemdziesiatych XX wieku w niektórych dużych parafiach osiedlowych w Polsce, istniała praktyka udzielania małżeństw większej liczbie nupturientów podczas jednej ceremonii. Przy tej okazji dochodziło czasami do przeoczenia, polegającego na pominięciu przez jakąś parę słów przysięgi małżeńskiej. Sądy kościelne, rozpatrujące takie sprawy musiały stwierdzać potem nieważność małżeństw z powodu braku formy kanonicznej, wynikającej z nieużycia przez szafarzy formuły sakramentalnej.

W Kościele prawosławnym nieważnym z powodu braku formy sakramentu, jest małżeństwo, podczas zawierania którego, kapłan nie zastosował przepisanych w jego obrządku słów uroczystego błogosławieństwa. Ponadto w katolickich Kościołach wschodnich, gdzie do ważności formy należy również złożenie przez nupturientów przysięgi małżeńskiej ${ }^{77}$, w przypadku, kiedy przez miesiąc kapłan jest nieosiągalny, lub nie można się do niego udać bez poważnej niedogodności, albo pojawiło się u któregoś z nupturientów niebezpieczeństwo śmierci, wystarczająca jest forma zawierająca tylko formułę sakramentalną przysięgi małżeńskiej, złożonej w obecności samych świadków, bez błogosławieństwa kapłana ${ }^{78}$.

\section{Zakończenie}

Bóg jest twórcą małżeństwa. Przymierze małżeńskie, przez które mężczyzna i kobieta tworzą ze sobą wspólnotę całego życia, zostało między ochrzczonymi przez Chrystusa podniesione do godności sakramentu $^{79}$. Każdy sakrament posiada swój znak, czyli gest wykonywany za pomocą słów i czynności przez szafarza oraz formę, którą stanowi formuła liturgiczna, wypowiadana w momencie jego udzielania. Brak należytej materii $\mathrm{i} /$ lub formy skutkuje nieważnością sakramentu, czyli faktem jego faktycznego niezaistnienia. Materia i forma niektórych sakramentów zostały przez Jesusa ustanowione wprost, innych, w tym również małżeństwa, nie dostapiły szczegółowego określenia. Stąd proces ich kształtowania dokonywał się na przełomie wielu

\footnotetext{
${ }^{76}$ Z. Janczewski, dz. cyt., s. 220.

${ }^{77}$ Kan. 837 \& 1 KKKW.

${ }^{78}$ Kan. 832 KKKW.

${ }^{79}$ Kan. 1055 § 1 KPK.
} 
wieków. Zauważa się przy tym nieco odmienne podejście do tej kwestii w Kościołach katolickim i prawosławnym.

W Kościele katolickim, nieodzownym elementem, „stwarzającym” małżeństwo, czyli jego materią, jest wzajemne wyrażenie zgody przez nupturientów. Wykonanie tego gestu konsensualnego, przynosi samo przez się łaskę sakramentalną. W koncepcji prawosławnej przymierze małżeńskie staje się sakramentem, nie na mocy konsensu stron, ale poprzez interwencję kapłańską (biskupa albo prezbitera), czyli udzielenie uroczystego błogosławieństwa, przy obrzędzie tak zwanej koronacji. Modlitwa inwokacyjna błogosławieństwa Bożego wywołuje skutki sakramentalne. Kapłan, a nie jak to ma miejsce u katolików łacińskich sami małżonkowie, jest więc tutaj szafarzem sakramentu. W katolickich Kościołach wschodnich, uznających zwierzchnictwo Stolicy Apostolskiej, znak sakramentalny będący jego formą, współistnieje istotowo w zgodzie stron złączonej z błogosławieństwem kapłańskim.

Formę sakramentów stanowią słowa szafarza wypowiadane podczas ceremonii ich sprawowania. W przypadku małżeństwa, należy wyraźnie odróżnić formę jego zawarcia, określoną przez prawo kanoniczne, od formy sakramentu, ujmowanej w prawie liturgicznym. W Kościele katolickim formą omawianego sakramentu są słowa przysięgi małżeńskiej, przewidziane przez księgę Obrzędów sakramentu małżeństwa. Faktem jest, że wspomniana księga liturgiczna przewiduje wypowiedzenie przez nupturientów zgody niejako dwukrotnie. Za pierwszym razem są to jednak tzw. skrutinia, czyli pytania wstępne, proklamujące w liturgii, w obliczu całej zgromadzonej wspólnoty, warunki wymagane do zawarcia małżeństwa. Natomiast drugi tekst, rozpoczynający się słowami: „Ja... biorę sobie ciebie...,” jest właśnie wyrażeniem konsensu, stanowiącym formułę sakramentalną. W przypadku omawianego sakramentu, dla osób niepotrafiących mówić, formę mogą stanowić również istotne gesty, wykonywane na przykład w języku migowym.

W Kościołach wschodnich, prawosławnym i katolickich, formą sakramentu małżeństwa są słowa modlitwy liturgicznej uroczystego błogosławieństwa. Liturgie tam celebrowane zawierają wiele tekstów, w których prosi się Boga o takie błogosławieństwo. Ponadto u katolików wschodnich formułą sakramentalną jest równocześnie tekst przysięgi małżeńskiej.

Istotne wady materii $\mathrm{i}$ formy sakramentu małżeństwa powodują jego nieważność. Do wad materii zaliczmy między innymi wady 
zgody małżeńskiej, przewidziane przez Kodeks prawa kanonicznego. Wynika to pośrednio z faktu nierozdzielności kontraktu małżeńskiego i sakramentu. Taką nieważność spowoduje także, w przypadku małżeństwa zawieranego przez pełnomocnika, cofnięcie przez mocodawcę swojej zgody na związek, przed lub w czasie jego zawierania. Powodem nieważności może się stać sytuacja, w której funkcję pełnomocnika w odniesieniu do obojga nupturientów pełniłaby jedna osoba, albo druga ze stron. Innym powodem niezaistnienia sakramentu, byłoby posłużenie się podczas ceremonii ślubnej nowoczesnymi środkami komunikowania się, jak np. telefonem albo Internetem, ponieważ wyrażenie konsensu ma się odbywać jednocześnie i osobiście, przy fizycznej obecności nupturientów.

Wadami formy sakramentu, powodującymi jego nieważność są przede wszystkim niezastosowanie formuły sakramentalnej, czyli tekstów liturgicznych wymaganych przy składaniu przysięgi małżeńskiej i udzielaniu błogosławieństwa kapłańskiego albo, kiedy słowa formuły różnią się istotnie od wymaganych. Dopuszcza się jedynie ich drobną modyfikację, czyli zmianę akcydentalną.

\section{The matter and form of sacrament marriage}

Two of few elements which have an influence on validity of the sacraments administration are the matter and form. The most important is the fact if they were defined directly by the very Jesus Christ and they are in the deposit of revelation. Otherwise, they are defined by the Church, which specifies them by means of canonical and liturgical law, the conditions for a sacrament to be valid. The gesture of a minister of a sacrament is the matter of a given one, which is necessary for validity of an act and for receiving a sacramental grace, while the words spoken by him during the celebration of a sacrament (that is a sacramental formula), included in the liturgical books, constitute the form.

But is a problem with sacrament of marriage. The matter and form of such sacrament are different in the Roman catholic and orthodox Churches. In the first of those the matter is matrimonial consent. It is an act of will by which a man and a woman by an irrevocable covenant mutually give and accept one another for the purpose of establishing a marriage. The form is formula of consent. In the orthodox Church the matter is priest's or bishop's blessing, and the form is formula of such blessing. This article shows history of the matter and form of those sacrament and various problems relative this questions. 